\title{
GOVERNMENT INTERVENTION IN DETERMINING PRICES ACCORDING TO IBN TAIMIYAH'S
}

\author{
Khanifah Nurfaizah'1 \\ 'Program Pascasarjana Ekonomi Syariah IAIN Purwokerto \\ Email: khanifahnurfaizah16@gmail.com (correspondence author)
}

\begin{abstract}
Government intervention in pricing, has always been debated among economists. Islam as a religion which the last has a good economic outlook in terms of micro, macro as well as domestic scale, regional and even international. Prophet was the first in Taimiyah's book by the public regarding the intervention price, at the time of the Prophet give answers like the following hadith "From Anas bin Malik, he said: the price of goods once expensive at the time of the Prophet. then people said: Messenger of Allah, the prices to be expensive, set a standard price for us, the Messenger of Allah said: Surely it is God who sets the price, holding and distributing rizki, and indeed just hoped that I could meet Allah in a state no one among you who prosecute me because of the injustice in the bloodshed (killer) and treasures. "(HR. Abu Dawud, Ahmad, Tirmidhi and Ibn Majah)" based on the tradition is causing debate among scientists, they have a different view of these traditions. One of them Muslim scientist Ibn Taymiyyah who see his government intervention in pricing, Ibn Taymiyyah was found Ibn Taymiyyah, found the price to be considered by the forces of supply and demand. due to a shortfall in production or a decrease in imports of goods requested. So, if the need to increase the number of goods, while the ability to provide it decreases, prices will naturally increased. Determines prices by Ibn Taymiyyah can be divided into two types, namely injustice and tyranny of elements. found the price to be considered by the forces of supply and demand. due to a shortfall in production or a decrease in imports of goods requested. So, if the need to increase the number of goods, while the ability to provide it decreases, prices will naturally increased. Determines prices by Ibn Taymiyyah can be divided into two types, namely injustice and tyranny of elements. found the price to be considered by the forces of supply and demand. due to a shortfall in production or a decrease in imports of goods requested. So, if the need to increase the number of goods, while the ability to provide it decreases, prices will naturally increased. Determines prices by Ibn Taymiyyah can be divided into two types, namely injustice and tyranny of elements. Intervention pricing allowed even obligatory in Islam for the benefit of welfare society.
\end{abstract}

Keywords:Price fixing intervention, Ibn Taimiyah 


\section{Introduction}

Islam is a good religion in regulating life, including in the economic field. In Islam not only regulates human relations with God, but also regulates good relations in everyday life. Values in Islam are universal, not only for fellow Muslims but apply to all nations in the world.

This phenomenon will become widespread when entrepreneurs and industry (generally the general public) need or face problems that concern and relate to the needs of many people. One party wants the government not to intervene in managing or managing an economy, just the private sector or entrepreneurs. On the other hand, the community or entrepreneurs themselves (industry circles might) actually do not want the government to take their hands off in dealing with an economic problem, perhaps for fear of taking on too much risk or even being unable to be trusted by the private sector by the community.

The role of government intervention has become a common phenomenon in economic development, especially in developing countries. Interventions that exceeded capacity turned out to have led to economic distortions. Because the tendency is followed by the weak morality of economic agents who have turned into greedy and inefficient economic regimes. (Sumarni 2015)

The current economic system is an economic system controlled more by the liberal capitalist economy. Where what is pursued is individual satisfaction without regard to benefit. This economic system is very clear when price increases or scarcity of goods in the market due to unfair competition. Generating price volatility that cannot be controlled so that the price balance is unstable and has a major impact on the lower middle class.

This is very visible when approaching major holidays such as before Ramadan, Eid al-Fitr, Christmas, New Year and other holidays. Towards that day prices began to surge up as prices of groceries, transportation tickets and other necessities, rising prices of groceries were very prominent among the increase in other needs. The increase in the price of nine-basic necessities every day before the big day continues to increase every year and is difficult to stop. This can happen because of the hoarding of goods, speculators who want to take maximum profits without regard to the needs of the community.

Since before entering the big day, holy Idul-fitri day, the shops were full. Many people like to shop to meet the needs of the day. At that time, prices also crept up. This is what came to be called inflation. Inflation is defined as a rise in the general level of prices for goods and services, which in turn results in a decline in the purchasing power of a unit of money (Schwab and Peter Lusztig 1970)

Inflation is a term for the phenomenon of rising prices of goods in society. The emphasis is not on "rising prices for goods", but on the "phenomenon" of the process of continually increasing prices for goods caused by various factors, ranging from increased consumption (demand is higher than supply), non-smooth distribution processes, or an abundance of money supply. The price of goods that rise causes a decline in the value of the currency. This process continues and influences the prices of other goods.

In order to protect the rights of sellers and buyers, Islam allows the government to intervene in price interventions, or in Islamic Fiqh, known as Tas' ir, namely price fixing or intervention by the government in determining prices on the grounds of benefit. Khulafaur Rasyidin had also intervened in determining the price, namely when Umar bin Khattab r.a. came to the market and found that Habib bin Abi Balta 'sells dried wine at prices below market prices. Umar immediately rebuked him: "Raise your price or leave our market" (Karim 2014). Ibn Taymiyah argues that price determination follows the market mechanism and relies on the argument that the real price is God's will.

The price fixing mechanism is that the government seeks to supply the commodity in question and adjust it to market demand. Conversely, if there are quite a lot of goods in the market, but prices continue to rise, the government needs to exercise strict supervision.

\section{Literature Review}

\subsection{Concept of Price}

In conventional economics, price theory is explained about how the market economy works (laissez faire without government intervention). Market price theory is the price of goods or services whose market is competitive, high and low determined by market demand 
and supply. The price system and the impersonal forces of supply and demand determines which products and services will be produced and which inputs will be used (Shaanan 2017).

The market mechanism is basically the price mechanism, the falling and rising prices as a result of a dynamics of demand (supply) and supply (demand) from related parties. A demand and supply are two forces that pull each other to form a market community (Adiwarman 2004)

There are two main factors that influence the quantity of goods demanded in the market, namely price and price no such as population, income level, price of substitute goods and consumer tastes. Between these two factors price is the factor that most influences the quantity of goods demanded in the market. The relationship between the price and the amount of goods purchased on the market is called demand, the "law of demand" states that the higher the price of the goods, the less consumers buy the goods. Conversely, the lower the price of goods the more consumers buy these goods. (Hartono 2006).

In Islamic economics, every economic decision of a human being is inseparable from moral and religious values because every activity is always related to the Shari'a. The Qur'an refers to economics in terms of iqtishad (austerity, economy), which literally means mid or moderate. A Muslim is forbidden to waste, this is explained in Al-Qu'an Surah Al-Isra 'verses 2627

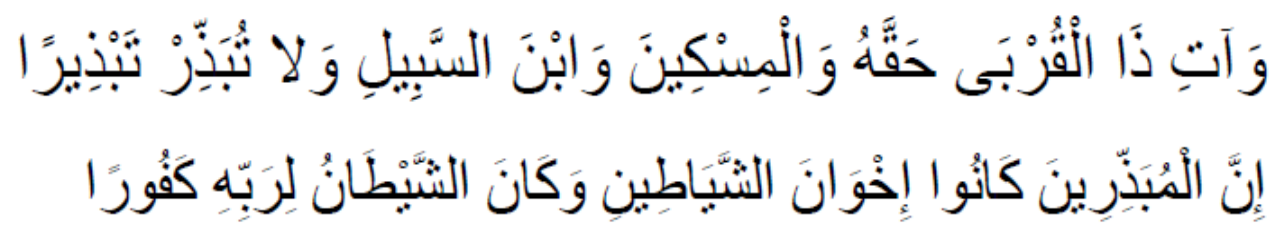

And give to families who are close to their rights, to the poor and those who are on their way; and do not waste (your wealth) wastefully.

Supply (supply) shows the relationship between the price and the amount of goods offered or sold in the market. Besides the price factor, the amount of goods offered in the market is also influenced by non-price factors such as the cost of production factors, related goods, technology, and the number of producers. The law of supply states that the higher the price of goods, the more goods are offered in the market. Conversely, the lower the price of goods, the less goods are offered in the market.

\subsection{Market Distortion}

Market distortion is a disorder that occurs with a perfect market mechanism. In general, the emergence of Islamic moral messages in market theory is a response to the verses of the Koran and the hadith that teach that the market must run well, fairly, not harming anyone. When tracing a few verses in the Koran, it is clear that Islam's attention to the market is quite large (Harahap 2017).

In economic terminology, a free market is a market that illustrates that buyers and sellers compete with each other transparently based on the joints of justice, there are no individuals or groups, producers or consumers let alone governments that are wronged or wronged. In the Islamic business world where the meeting between the demand for a particular item and its offer occurs on the basis of like, like, willing to be willing and no party feels cheated or there is an error in the transaction object in certain goods transaction at a certain price level.

In reality, the market mechanism does not always work well, there is often a disturbance that causes the market mechanism to be not ideal. This disruption to market mechanisms is called market distortion. Broadly speaking, there are four forms of market distortion, namely: Distortion of supply and demand, Tadlis (Fraud) and Taghrir (Chaos). The details of the explanation are as follows:

1. Distortion of supply and demand In Islamic economics, the term supply distortion is identical to intikar. This is based on the words of the Prophet Muhammad, as follows "From Said ibn Musayyab, from Ma'mar ibn Abdullah sourced from the Messenger of Allāh SA said: There is no one intikar unless he has sinned. "(Narrated by Abu Dawud) Ulama identify several factors that cause the practice of intikar in a market, as follows: 
a. Efforts to eliminate or minimize goods by stockpiling or other means;

b. Selling at a price higher than the price before scarcity occurs;

c. Take a higher profit than profit before $a$ ) and b) is done.

As for the distortion of demand identical to bai 'najasy, a seller tells someone to praise the superiority of his trading commodities and to make offers at a high price that he is actually not interested in buying these commodities, but to lure others to buy trading commodities at prices higher than the price normal in these markets. (Hilal 2014)

2. Tadlis (Fraud)

Tadlis (fraud) is caused by incomplete information. Every transaction in Islam must be based on the principle of willingness between the two parties. They must have the same information about the traded goods, both in terms of quality and quantity, as well as the sale price and time of receipt. So that no one feels disadvantaged in this matter, and no party feels cheated. (Adiwarman 2004)

3. Taghrir (Uncertainty of both parties).

Lexically, said taghrir, means: effect, disaster, risk, danger, and uncertainty. (Dhaif, 2011) The terminology is to do something blindly without the support of adequate knowledge or someone who is willing to bear the risk of an act without knowing the type the risk he will accept. (Rahman 1996). Unclear buying and selling is buying and selling that contains the element of gharar. (At-Tariqi 2004). Prophet Muhammad SAW said: and buying and selling gharar "(HR. Muslim).

Tadlis is motivated by incomplete information that befalls one of the parties, namely the buyer. While Taghrir caused by incomplate information experienced by both parties, namely the seller and buyer.

\subsection{Biography of Ibn Taimiyah}

Taqiyuddin Ahmad bin Abdul Halim or known by the name Ibn Taimiyah was born in the city of Harran on January 22, 1263 AD / 10 Rabiul Awal 661 H. Ibn Taimiyah came from a highly educated family and included a great scholar of the Hambali School. For his genius, from a young age he had completed several subjects, such as jurisprudence, interpretation, hadith, philosophy and mathematics and became superior among his friends. He has 200 teachers, including Syamsuddin Al Maqdisi, Ibn Abi Al Yusr, Ahmad bin Abu Al Khair and Al Kamal bin Adul Majd bin Asakir. With his thought that was considered revolutionary and reformer, and his ijtihad in the field of muamalah made his name even more famous throughout the world.

In political life, he has been in prison four times. This was caused by his fatwa which was considered to be in conflict with the government at that time. while in prison, he spent a lot of time writing and teaching. He breathed his last on September 26, 1328 AD (20 Zulqa'idah $728 \mathrm{H})$.

This Islamic reformer also has many fantastic scientific works. He has a book that describes the law, economics, philosophy and others. Ibn Taymiyyah also discussed economic principles written in his two books, namely al-Hisbah fi al Islam (hisbah institution in Islam) and al-Siyasah al Syar'iyyah fi Ishlah al Ra'i wa al Ra'iyah (public law and private in Islam). The first book deals with the market and government intervention in the economic field, while the second book discusses public revenue and financing. (Farma 2018).

\subsection{Thought of Ibn Taimiyyah in Pricing}

Price is very important in the market mechanism, Ibn Taymiyyah gives special attention to price issues. The aim is to emphasize fairness over prices circulating in the market and to meet the basic needs of the community.

Based on the discussion above, Rasulullah explained in his hadith: "From Anas bin Malik he said: the price of goods was once expensive during the time of the Prophet. then people say: O Messenger of God, prices become expensive, set a price standard for us, then the Messenger of Allah said: Verily, Allah is the one who sets the price, holds back and distributes wealth, and actually just hopes that I can meet Allah in the circumstances none of you will sue me for wrongdoing in the bloodshed (murderer) and treasure. " (Narrated by Abu Daud, Ahmad, Tirmidhi and Ibn Majah) (Amalia 2005)

Ibn Taimiyah responded to the hadith of the Prophet Muhammad SAW mentioned above 
that the Prophet Muhammad did not intervene in the price at that time, by looking at the following matters:

1. Because wurud or background to the emergence of the hadith is started from something special and not from a general problem that applies to all cases;

2. In that market there are no merchants who refrain from selling goods that must be sold or services that are required to do so;

3. Market conditions at that time are in normal conditions which are subject to the law of supply and demand. (Hilal 2014)

From the above hadith problem that the price increase at that time was not caused by market imperfections, but because of the strength of demand and supply so that the Prophet did not intervene in the price at that time. Meanwhile, according to Ibnu Taimiyah, saying that price intervention (by the Prophet / government) to meet the needs of just one person can be done, then it would be more logical if similar things (price intervention by the government) were carried out to meet the needs of many people related to food, clothing and housing because public needs are far more important than personal needs (Taimiyah.)

According to Ibn Taymiyyah, a price is considered by the strength of supply and demand. due to a deficiency in production or a decline in imports of the requested goods. So, if the demand for the number of goods increases, while the ability to supply it decreases, the price will automatically increase. On the other hand, if the ability to supply goods increases and demand decreases, prices will fall. Scarcity and abundance are not necessarily caused by one's actions. It could be related to a cause that does not involve injustice. Or caused by injustice (Yassine Essid 1987). Pricing according to Ibn Taimiyah (Syamsul 2014) can be divided into two types, namely:

1. Fixing prices that are unfair or contain elements of injustice

Ibn Taymiyah explained the market mechanism and price regulation in his book entitled al-Hisbah fi al-Islam and Majmu 'Fatawa Shaikh al-Islam Ibn Taimiyah. Ibn Taimiyah has a clear understanding of how things happen in a free market, that is, prices are determined by the forces of demand and supply. Ibn Taimiyah argues that rising and falling prices are not always caused by the tyranny of certain people. Sometimes, this is caused by a lack of production or a decrease in the import of the requested goods. Therefore, if demand rises and supply falls, prices rise. On the other hand, if the supply of goods increases and the demand for it decreases, the price also falls. Scarcity or abundance is not caused by the actions of certain people. It could be caused by something that does not contain tyranny, or sometimes it can also be caused by tyranny. This is God's power that has created desires in the hearts of men.

Fair pricing according to law

The concept of fair prices has essentially been around and used since the very beginning of the Islamic presence. The Koran itself emphasizes the eighth in every aspect of human life. Therefore, it is natural that justice is also realized in market activities, especially prices. Related to this, Rasulullah SAW classified usury as an excessively expensive sale that exceeded consumer confidence.

The term fair price has also been mentioned in several prophetic traditions in the context of an owner's compensation, for example in the case of an employer who frees his slaves. Even though the use of the term has existed since the early days of Islam, Ibn Taymiyyah appeared to be the first to pay special attention to the issue of fair prices. In discussing issues related to prices, he often uses two terms, namely equal compensation ('iwadh al-mitsl) and equivalent prices (tsaman al-mitsl).

From this statement it can be understood that everyone is free to enter and enter the market. However, monopolistic elements and all forms of product fraud, collusion and counterfeiting must be removed from the market. In addition, if an emergency occurs, such as a famine, the government must set prices and may force traders to sell basic needs, such as food needed by the community.

Ibnu Taimiyah also explained that before the price was set, the government had to hold a meeting with the community or market representatives first. This is persuasive because the government offers bargaining participants in terms of pricing, so that the results of the decision can be agreed by all parties (Amalia 2005). If seen from the pricing concept offered by Ibnu Taimiyah is a very good illustrative example. In the view of Ibn Taymiyyah, the fulfillment of basic human needs is the responsibility of the state or government, both food, 
clothing, shelter and so on. Therefore, the pricing done by the government is considered good, but it is not absolute. Only under certain conditions can the government interfere in setting prices, such as rising prices due to injustice or inequality of market mechanisms caused by the seller's actions. For that, we need a board that can balance the interests of buyers and sellers. Under such conditions, supervision is now recommended for the increase in prices (Islahi and Thayib 1997)

In addition, Thomas Aquinas (Western economist) also discusses the market price (just price), the idea comes from Aristotle. However, if explored further, the thought of Ibn Taymiyyah about this matter is far more comprehensive than that of Aquinas. Both of them argue that market prices must occur in a perfectly competitive market. Then, they allow the ceiling to be set when there is a difference in the price of the market price. But the opinions of these two figures differ, where Aquinas only considers subjective values from the seller's side only, whereas Ibn Taymiyyah also considers subjective values from the buyer's side, so that Ibnu Taimiyah's analysis is considered better than Aquinas. (Fauzia 2014)

As is the case in Indonesia, there are often fluctuations in the prices of basic necessities which are not only caused by the high demand, but also the dependence on imported commodities. If related to the thought of Ibn Taymiyyah, when price instability occurs, where the price of basic necessities rises because of manipulation or monopolistic practices of a group of people, then in this case the government must set prices. The reality is that the government has been very easy to solve the problem of rising prices of domestic goods, namely by importing goods from abroad. Though this method is not including the right way, because it only resolves the problem for a moment. The government should implement longterm policies in overcoming this problem, one of which is by accelerating the increase in domestic production and improvement of the domestic market. The policy is expected to meet the supply of goods needed by the community, so prices will be more stable and can be reached by all levels of society. (Farma 2018)

In this case the role of the government in maintaining the market mechanism is very important, either as a regulator or supervisor of the market mechanism so that it runs perfectly so as to create a fair price for sellers and buyers.

\section{Research Methods}

The study method used is a literature study by gathering various previous research as a reference and various documents related to Government Intervention in Determining Prices According to Ibn Taimiyah's.

\section{Results and Discussion}

Based on the discussion above, that pricing according to Ibn Taymiyyah. The fall and increase in prices as a result of a dynamics of demand and supply from related parties. A real demand and supply because the availability of existing goods are two forces that pull each other so that it forms a market community in determining prices. In today's economy what is called market price.

If the distortion of supply and demand, Tadlis (Fraud) and Taghrir (Chaos) occur, such as unreal demand, or monopolized supply, then it will be the cause of imperfect market mechanism in the determination. So in the condition of market imperfection, Ibn Taymiyyah recommends price fixing by the government, a fair price for the community will be obtained. Such conditions the government is obliged to set a fair price for sellers and buyers by making decisions must be persuasive by offering price decisions that are supported by all market participants.

Price-setting interventions are allowed and even required in Islam for the benefit of the people's welfare. The easiest example is protecting prices from cheap goods attacks originating from importers for small and medium businesses (SMEs). The positive impact of price regulation is very helpful for SMEs in facing market manipulation that is generally carried out by suppliers of cheap imported goods. So that policies which are in line with Ibn Taymiyah's thoughts can be used by the government to protect the micro business sector from the destruction of its business.

The thought of Ibn Taymiyyah was very concerned about the state of the market, because the market was the joint and center of the people's economy. Ibnu Taymiyah even 
thought that orders must have an attitude in monitoring prices circulating in the market, conducting investigations, and being able to intervene or set prices, especially if there is a market failure in determining prices, then the government is obliged to intervene in price with the terms and conditions that in holding supervision, investigation, and pricing, must be done by deliberation, must agree on the results of the deliberation

\section{Conclusions}

Based on the discussion above, it can be concluded that the pricing according to Ibn Taymiyyah

1. The fall and increase in prices as a result of a dynamic demand (supply) and supply (demand) from related parties. A demand and a supply are two forces that pull each other to form a market community in determining prices.

2. Imperfect market mechanisms in determining prices are caused by supply and demand distortion, Tadlis (Fraud) and Taghrir (Chaos).

3. During the time of Rasulullah Price intervention was carried out on market imperfections.

4. Ibn Taymiyyah is a Muslim scientist where the sharpness of the questioner has produced monumental scientific work and touched various aspects of the problems of Muslims including economics, who are very concerned in terms of pricing.

5. Ibn Taymiyyah, argues that prices are considered by the strength of supply and demand. because of a deficiency in production or a decline in imports of the requested goods. So, if the demand for the number of goods increases, while the ability to supply it decreases, the price will automatically increase

6. Pricing according to Ibn Taymiyyah can be divided into two types, namely injustice and the element of injustice.

7. Price-setting interventions are allowed even required in Islam for the benefit of the welfare of society.

\section{References}

[1]Adiwarman, Karim. 2004. "Bank Islam: Analisis Fiqih Dan Keuangan." Jakarta: PT. Raja Grafindo.

[2] Amalia, Euis. 2005. Sejarah Pemikiran Ekonomi Islam: Dari Masa Klasik Hingga Kontemporer. Pustaka Asatruss.

[3]At-Tariqi, Abdullah Abdul Husain. 2004. "Al-lqtishad Al-Islami: Ushusun Wa Muba'un Waakhdaf." Terjemahan, Yogyakarta: Magistra Insannia Press.

[4]Farma, Junia. 2018. "Mekanisme Pasar Dan Regulasi Harga: Telaah Atas Pemikiran Ibnu Taimiyah." Cakrawala: Jurnal Studi Islam 13 (2): 182-93.

[5]Fauzia, Ika Yunia. 2014. Prinsip Dasar Ekonomi Islam Perspektif Maqashid Al-Syariah. Kencana.

[6]Harahap, Isnaini. 2017. Hadis-Hadis Ekonomi. Prenada Media.

[7]Hartono, Tony. 2006. Mekanisme Ekonomi: Dalam Konteks Ekonomi Indonesia. Remaja Rosdakarya.

[8]Hilal, Syamsul. 2014. "Konsep Harga Dalam Ekonomi Islam (Telah Pemikiran Ibn Taimiyah)." ASAS 6 (2).

[9[Islahi, Abdul Azim, and Anshari Thayib. 1997. Konsepsi Ekonomi Ibnu Taimiyah. Bina llmu.

[10]Karim, Adiwarman Azwar. 2014. "Ekonomi Mikro Islami Cet. VI, Ed. V." Jakarta: Rajagrafindo Persada.

[11]Rahman, Afzalur. 1996. "Doktrin Ekonomi Islam, Jilid IV, Yogyakarta: PT." Dana Bhakti Wakaf, HIm 162.

[12]Schwab, Bernard, and Peter Lusztig. 1970. "A Note on Abandonment Value and Capital Budgeting Author ( $s$ ): Source: The Journal of Financial and Quantitative Analysis, Vol . 5, No . 3 ( Sep ., 1970 ), Pp . 377- Published by: Cambridge University Press on Behalf of the University of Washington S." The Journal of Financial and Quantitative Analysis 5 (3): 377-79.

[13]Shaanan, Joseph. 2017. America's Free Market Myths: Debunking Market Fundamentalism. America's Free Market Myths: Debunking Market Fundamentalism. 
https://doi.org/10.1007/978-3-319-50636-4.

[14]Sumarni. 2015. "'Intervensi Pemerintah" Antara Kebutuhan Dan Penolakan Di Bidang Ekonomi." Economica 1 (2): 183-94. https://doi.org/10.22202/economica.2013.v1.i2.118.

[15]Syamsul, Hilal. 2014. "Konsep Harga Dalam Ekonomi Islam (Telah Pemikiran Ibn Taimiyah)." Asas 6 (2): 16-28. https://doi.org/https://doi.org/10.24042/asas.v6i2.1718.

[16]Yassine Essid, M. 1987. "Islamic Economic Thought." Pre-Classical Economic Thought, 77102. https://doi.org/10.1007/978-94-009-3255-5_6. 